\title{
Archivio antropologico mediterraneo
}

Anno XXII, n. 21 (2) | 2019

Varia

\section{Vulnerability and Housing Policies through the Lens of Anthropology. An Introduction}

Vulnerabilità e politiche abitative attraverso lo sguardo dell'antropologia.

Un'introduzione

Giacomo Pozzi, Rita Ávila Cachado and Ana Luísa Micaelo

\section{OpenEdition}

Journals

Electronic version

URL: http://journals.openedition.org/aam/2067

ISSN: 2038-3215

Publisher

Dipartimento Culture e Società - Università di Palermo

Electronic reference

Giacomo Pozzi, Rita Ávila Cachado and Ana Luísa Micaelo, « Vulnerability and Housing Policies through the Lens of Anthropology. An Introduction », Archivio antropologico mediterraneo [Online], Anno XXII, n. 21 (2) | 2019, Online since 31 December 2019, connection on 01 January 2020. URL : http:// journals.openedition.org/aam/2067

This text was automatically generated on 1 January 2020.

Archivio antropologico mediterraneo 


\section{Vulnerability and Housing Policies through the Lens of Anthropology. An Introduction}

Vulnerabilità e politiche abitative attraverso lo sguardo dell'antropologia. Un'introduzione

Giacomo Pozzi, Rita Ávila Cachado and Ana Luísa Micaelo

1 The Dossier «Vulnerability and Housing Policies. Anthropological insights across Europe» is the result of a panel organized by the editors at the 15th EASA Biennial Conference hosted by Stockholm University in August $2018^{1}$. The theme of the conference was «Staying, Moving, Settling». Starting from the double consideration that, on one side, mobility has long been a topic in anthropological research and, on the other side, that recent times, for much of humanity but not only in Europe, have been marked by an heterogeneous mobility, the conference shed light to contemporary forms of mobility worldwide.

2 In this context, we then proposed to explore housing policies as peculiar and paradigmatic forms of contemporary «regimes of mobility» (Salazar, Glick Schiller 2014). This approach invites to analyse housing policies as part of a wider configuration of «relationships of unequal power within which relative stasis and different forms of mobility are constructed and negotiated» (Glick Schiller, Salazar 2013: 194).

Coherently to the panel target, the main theme of this Dossier is the anthropological analysis of the production of social and political vulnerability in Europe through housing policies. In particular, the ethnographies hosted in this Dossier explore the dense intersection between different configurations of social and political action, such as housing rights, residents' responses to public policies, vulnerability, real estate politics, migration, forced evictions, infrastructures. It is impossible to understand contemporary Europe, we argue, without understanding what is going on with housing policies. 
Mobility, associated with housing, can be examined through different perspectives and scales: observing for example movements between different residence locations in one single city or «remigration» processes for new countries (Dias 2017) - hence in a regime of transnational mobility (Glick Schiller, Çağlar 2009). In general, the nexus between mobility and housing seems - from the point of view of the residents - to be based on individual or familiar intention to look for better housing conditions, but also for social mobility (Grimaldi 2019). Here, we understand social mobility not in the classical sense of change - from one generation to the other - for a more advantageous place among social classes, but specially in the sense of citizenship. While dealing with housing policies, different residents see themselves in the situation of being compelled to understand the process in course and, in face of that process, to resist or adapt it (Cachado 2013). Therefore, processes of demolition and eviction - such as the ones presented in this Dossier - go along with dwellers' resistance and adaptation. Moreover, there are also housing policies that address social status, as in the case of Poland (Lehecka in this Dossier), where private ownership is presented (and accepted) as a component of acquiring, precisely, social status, along with the implicated mortgage.

5 The ethnographic accounts presented in this Dossier show that housing represents a material, political and symbolic crux in social and economic mobility, establishing the political boundaries of those who are seen as eligible buyers, (il)legitimate dwellers, natives or newcomers. Therefore, housing policies also define those who should "stay" and those who should "move", not only on the local scale but also on the national and transnational level.

On one hand, as a symbolic, social and spatial phenomenon, housing vulnerability is a particular form of forced mobility loaded with great anthropological significance (Carsten 2018). On the other hand, different housing policies, implemented in tension between rights and contention, markets and families (houses as assets/homes), hold a privileged task in governing the population, by determining both mobility and settling processes.

7 We can then ask, for the cases of forced mobility as a result of housing policies, what are the chances for the populations envisioned in those policies to really "settle" - a permanent concept used in housing vocabulary - in cities and neighbourhoods? What are their chances to place-making and be full citizens? Forced mobility deterritorializes the people who experience it by casting them into a situation of extreme social and economic vulnerability, removing them from a life space that represents their «home», «shell», «shield», «habitat» or «bubble» of protection from a reality they perceive as particularly complicated to manage. At the same time, as demonstrated in depth elsewhere (Pozzi 2019), eviction and resettlement also redefine the limits of belonging and citizenship, marginalizing those who suffer it even to the point of reproducing paradoxical forms of «internal foreignness».

8 Taking inspiration from the case of Italy, demonstrated by Pozzi in his article about Milan, housing vulnerability seems to be propagated also by a certain «bureaucratic indifference» (cfr. Herzfeld 1992, Graeber 2016). This «bureaucratic indifference» intended as a peculiar and technical governmental management of public policies - is rooted in a process of identity building - permeated with symbolic and local connotations - and differential profit-based relations between classes, although such 
relations can be different according to the political context of reference (Desmond 2016).

9 Framed in relation to «expulsion logic» (Sassen 2014), evictions - and in general forced mobilities - are analyzed through an approach that begins by stressing the interconnections among vulnerability, policies (on different scales) and agency of social actors. Pozzi argues that the rules and practices associated with expulsion policies and specifically evictions and forced removals - should be understood primarily as manifestations of state power. Through (formal and informal) collaboration between private or semi-private sector agents and agencies on one hand, and local institutions on the other, the state uses such policies in an effort to (re)establish a certain distributive order in terms of home ownership, access, and use, thereby giving rise to differential forms of «citizenship».

We can thus approach domestic space as an intimately political arena (Vasuvedan 2017) that is closely connected to governmental ambitions and divergent political rationalities (Blunt, Dowling 2006; Harker 2009; Brickell 2012; Arrigoitia 2014). At the same time, such an approach forces us to thoroughly consider the link between the global and local in order to investigate the practices and meanings of local policies and geographically, historically and socially determined local relationships (See Cachado and Frangella in this Dossier). And finally, this perspective invites us to explore the close ties between territorial security and development, as Brickell, Arrigoitia and Vasuvedan have suggested (2017).

11 These manifestations of state power are enacted and granted meaning in everyday life by both state agents and citizens themselves; as a result, they end up being manipulated, interpreted or mystified in relation to the specificities of the individual situation in question (see Pozzi in this Dossier). But expulsion and eviction deserve further insight before entering other anthropological and ethnographic insights hosted by this Dossier concerning housing vulnerability where histories of eviction, expulsion, displacement, forced relocation and resistance to these processes take place.

Such processes are analysed in different European countries - Czech Republic (Lehecka), Denmark (Bach), Italy (Pozzi), Portugal (Cachado and Frangella), - but more accurately, they take place in specific urban contexts - Prague, Aarhus, Milan, and Lisbon - with focus on the analytical debate about the (in)capacity of housing policies to promote stability, mobility or settlement. The papers cover a great diversity of situations that include expulsion, relocation and resettling, and they do it in different manners as we will see.

13 Expulsion has traditionally been analyzed as a form of spatial and economic control. Scholars have focused, on one side, on the structural causes of displacement as well as the socio-economic factors fostering it (Harvey 2004; Madden, Marcuse 2016) and, on the other side, on the people suffering these processes (Appadurai 2000). In agreement with Smart (2002) and Baker (2018), however, we must also concentrate on the way the structural dimensions of these specifics forms of regimes of forced mobility are performed and implemented in daily life, in order to understand the social (emotional, symbolic, relational, economic, local) impact they have on different social actors. Evictions, rehousing programmes, and even gentrification should be understood as complex and multidimensional social facts that span and crystalize the sphere of relations, tensions and inequalities characterizing the margins of the urban fabric, with margins in this case understood more as a subaltern configuration (cutting across 
different spaces) in the rhythms of a local economy than as a set of marginal positions in the hierarchy of urban space (see Pozzi, Rimoldi 2017).

As the reader may confirm, the Dossier holds four articles with diverse ways of explaining processes. If Pozzi's article offers an ethnographic example to explain, in depth, what eviction and expulsion means for a part of Milan citizens, which is somehow summarized in the title as "expulsionscape», the other articles also use illustrative vocabulary including metaphors to contribute to the debates concerning housing and vulnerability.

In the article by Michal Lehecka about Prague we are offered a comparation between two kinds of population dealing with privatization in a post-socialist time: Roma tenant residents who fear displacement and fantasize about private ownership, and a new population of mostly post-soviet immigrants who do their upmost to hold a property in Czech Republic. Comparing these situations, as it is a common way of analysing urban processes (Pickvance 1995), with a multi-sited ethnographic endeavour, Lehecka allows us as readers to understand Prague as a city "in transition" - as the author says - to a privatism era, where former and future dwellers bet on ownership to improve their social status. But Roma residents are being relocated to a segregated area. If it is true that Europe has been dealing with prejudice against Roma populations for centuries, the case presented by Lehecka shows that this problem increases when governments also have politics that underlies Roma social and spatial segregation.

The process in Gellerup, a neighbourhood sited in Aarhus (Denmark), is presented by Bach through an illustrative metaphor, the "demolition blues". Considering a big city plan that promotes, well intendedly, "anti-ghettization", the author unveils how the residents understand housing policies directed towards, ultimately, their lives and their homes. While describing a process, this article shows, however, good intentions go nowhere if the way communication is established does not reach the recipient or is not understandable.

The article about Lisbon presents the readers two insights from two migrant populations in the city, the Hindu and the Brazilian. Frangella and Cachado chose these very diverse contexts to show how housing policies, sometimes their unknowing, or their absence, provoke the decision to remigrate or to resettle in other parts of the city. They tell their migrant stories, which are also transnational migration stories, and that way they contribute to understand housing vulnerability under the vast scope of urban, social or other types of mobility, either forced, or chosen.

The contributions address different temporalities of such policies, whether in the short time of personal and family experiences or at the long-term of generations, neighbourhoods and cities, and other ties of social and local belonging. The focus lies on the variety of European practices, yet other empirical and comparative data addressing these topics will be present in the Dossier.

Beyond the ethnographic gaze, all the authors mix local bibliographies, enriching literature on housing and vulnerability, with common and classical literature. This way, the articles present processes more than isolated situations. And while doing this, they share with readers very vivid pictures of a group of urban processes, and ultimately, they contribute to enrich the contribution of urban anthropology to the comprehension of cities. 
Housing policies often include the idea of positive changes, as is very clear in the case of Denmark presented by Jonas Strandholdt Bach, where the policy analysed bet on neighbourhoods "de-ghettoization", but with a low effective communication between promoters and final recipients. This Dossier allows to look at a particular facet of Europe that lies precisely on a reconfiguration of cities with policies that sometimes overlook lower social classes, where large migrant populations are included. Reconfiguration of cities is generally well intentioned, but, as one resident interviewed by Bach said, «we know gentrification when we see it». In this sense, housing policies are better understood with the residents' perspectives that are brought by the authors in diverse ways.

21 Not all cases presented denote a «bureaucratic indifference» towards residents, but often hermetic language used in laws and in specific housing programs move them away from decisions while at the same time demand involvement in already decided processes. Nevertheless, residents somehow react to housing policies, either resisting or adapting to processes. In the same way of the residents, ethnographers should not be intimated by the "boring technicality" of public policies: as Shore and Wright stated, "policies can be studied as contested narratives which define the problems of the present» (Shore, Wright 2011: 13). With this Dossier, we want to underline that we - as social scientists - have urgent need to refine our interpretative tools for better understanding those kinds of narratives. Anthropology may give a fundamental contribution in this sense.

\section{BIBLIOGRAPHY}

Appadurai A., 2000, «Spectral Housing and Urban Cleansing: Notes on Millennial Mumbai», in Public Culture, 12: 627-651.

Arrigoitia M. F., 2014 «Unmaking public housing towers: The role of lifts and stairs in the demolition of a Puerto Rican project», in Home Cultures, 11, 2: 167-196.

Baker A.G., 2017 «Bailiffs at the Door: Work, Power, and Resistance in Eviction Enforcement», in K. Brickell, M.F. Arrigoitia, A. Vasudevan (eds.), Geographies of Forced Eviction. Dispossession, Violence, Resistance, Palgrave, London: 145-166.

Blunt A., Dowling R.M., 2006 Home, Routledge, London.

Brickell K., 2012 «Geopolitics of home», in Geography Compass, 6, 10: 575-588.

Brickell K., Arrigoitia M.F., Vasudevan A. (eds.), 2017 Geographies of Forced Eviction. Dispossession, Violence, Resistance, Palgrave, London.

Cachado R., 2013 «O registo escondido num bairro em processo de realojamento. O caso dos Hindus da Quinta da Vitória», in Etnográfica, 17, 3: 477-499

Carsten J., 2018 «House-lives as ethnography/biography», in Social Anthropology / Anthropologie Sociale, 26, 1: 103-116. 
Desmond M., 2016 Evicted. Poverty and Profit in the American City, Crown Publishers, New York. Dias N., 2016 Remigração e Etnicidade. Trânsito colonial entre a África de Leste e a Europa, Mundos Sociais, Lisboa.

Glick Schiller N., Çağlar. A., 2009 «Towards a Comparative Theory of Locality in Migration Studies: Migrant Incorporation and City Scale», in Journal of Ethnic and Migration Studies, 35, 2: 177-202.

Glick Schiller N., Salazar N.B. 2013 «Regimes of Mobility Across the Globe», in Journal of Ethnic and Migration Studies, 39, 2: 183-200.

Grimaldi G., 2019 «Oltre il ritorno: le case della diaspora come infrastrutture della mobilità», in B. Riccio (a cura di), Mobilità. Incursioni etnografiche, Mondadori, Milano: 94-110.

Harker C., 2009 «Spacing Palestine through the home», in Transactions of the Institute of British Geographers, 34, 3: 320-332.

Harvey D., 2004 «The New Imperialism: accumulation by dispossession», in Social Register, 40: 63-87.

Herzfeld M., 1992 The Social Production of Indifference: Exploring the Symbolic Roots of Western Bureaucracy, University of Chicago Press, Chicago.

Madden D., Marcuse P., 2016 In defense of housing. The Politics of Crisis, Verso, London.

Pickvance, C., 1995 «Comparative Analysis, Causality and Case Studies in Urban Studies», in A. Rogers and S. Vertovec (eds.), The Urban Context, Berg Publishers, Oxford, Washington: 35-54.

Pozzi G., 2019 «Un'ospitalità ostile. Etnografia delle politiche per gli sfrattati a Milano», in Meridiana. Rivista di storia e scienze sociali, 95: 195-221.

Pozzi G., Rimoldi L., 2017 «Marginal Uncertainties. Making a living and working in the outskirts of Milan», in EtnoAntropologia, 5,1: 95-108.

Salazar N.B., Glick Schiller N., 2014 Regimes of Mobility: Imaginaries and Relationalities of Power, Routledge, London.

Sassen S., 2014 Expulsions: Brutality and Complexity in the Global Economy, Harvard University Press, Harvard.

Shore C., Wright S.E., 2011 «Introduction. Conceptualising Policy: Technologies of Governance and the Politics of Visibility», in C. Shore, S.E. Wright, D. Però (eds.), Policy Worlds: anthropology and the analysis of contemporary power, Berghahn Books, Oxford: 1-26.

Smart A., 2002 «Agents of eviction: the squatter control and clearance division of hong Kong's housing department», in Singapore Journal of Tropical Geography, 23, 3: 333-347.

Vasudevan A., 2017 «Zwangsräumungen in Berlin: Towards an Historical Geography of Dispossession», in K. Brickell, M.F. Arrigoitia, A. Vasudevan (eds.), Geographies of Forced Eviction. Dispossession, Violence, Resistance, Palgrave, London: 191-214.

\section{NOTES}

1. In addition to the authors of the articles in this Dossier of AAM, participants in the panel «Vulnerability and housing policies: anthropological insights across Europe» of the 15th EASA Biennial Conference included Ana Luísa Micaelo, Anne Gronseth, Cansu Civelek, Maciej Witkowski and Ewa Nowicka. Then, we all set the basis of this stimulating debate and we are very 
grateful to everyone. We also thank the anonymous reviewers of the articles included in this Dossier for their helpful comments. And we are very pleased with all the support that the Journal gave us during the edition and publication process, especially to Gabriella D'Agostino, Editor of Archivio Antropologico Mediterraneo.

\section{ABSTRACTS}

The Dossier «Vulnerability and Housing Policies. Anthropological insights across Europe» is the result of a panel organized by the editors at the 15th EASA Biennial Conference hosted by Stockholm University in August 2018. In this context, we proposed to explore ethnographically housing policies as peculiar and paradigmatic forms of contemporary «regimes of mobility». Coherently to the panel target, the main theme of this Dossier is the anthropological analysis of the production of social and political vulnerability in Europe through housing policies. In particular, the ethnographies hosted in this Dossier explore the dense intersection between different configurations of social and political action, such as housing rights, residents' responses to public policies, vulnerability, real estate politics, migration, forced evictions, infrastructures. It is impossible to understand contemporary Europe, we argue, without understanding what is going on with housing policies. Anthropology may give a fundamental contribution in this sense.

«Vulnerability and Housing Policies. Anthropological insights across Europe» è il risultato di un panel organizzato dai curatori del dossier che qui si presenta alla $15^{\text {a }}$ Conferenza Biennale EASA ospitata dall'Università di Stoccolma nell'agosto 2018. In quel contesto, abbiamo proposto di indagare etnograficamente le politiche abitative come forme peculiari e paradigmatiche dei «regimi di mobilità» contemporanei. Coerentemente con l'obiettivo del panel, il tema principale del Dossier qui proposto è l'analisi antropologica della produzione di vulnerabilità sociale e politica in Europa attraverso l'implementazione di politiche abitative. In particolare, le etnografie ospitate nel Dossier esplorano la densa intersezione tra differenti configurazioni di azione sociale e politica, quali i diritti abitativi, le reazioni dei residenti alle politiche pubbliche, la vulnerabilità, le politiche immobiliari, la migrazione, gli sfratti, le infrastrutture. Sosteniamo che sia impossibile comprendere l'Europa contemporanea senza considerare quanto sta avvenendo sul piano delle politiche abitative. In questo senso, l'antropologia può dare un contributo fondamentale.

\section{INDEX}

Keywords: vulnerability, housing policies, regimes of mobility, ethnography, Europe Parole chiave: vulnerabilità, politiche abitative, regimi di mobilità, etnografia, Europa

\section{AUTHORS}

\section{GIACOMO POZZI}

University of Milano-Bicocca, Department of Human Sciences "Riccardo Massa", giacomo.pozzi@unimib.it 


\section{RITA ÁVILA CACHADO}

Instituto Universitário de Lisboa (ISCTE-IUL), Centro de Investigação e Estudos de Sociologia (CIES-IUL), rita.cachado@iscte-iul.pt

\section{ANA LUÍSA MICAELO}

Instituto Universitário de Lisboa (ISCTE-IUL), Centro em Rede de Investigação em Antropologia

(CRIA-IUL), ana.micaelo@iscte-iul.pt 